\title{
Three new species of Lepidemathis Simon, 1903 (Araneae: Salticidae) from the Philippines
}

\author{
Aimee Lynn A. Barrion-Dupo, ${ }^{1,2}$ and Alberto T. Barrion ${ }^{2,3}$
}

\begin{abstract}
Three new species of the pluridentate spider Lepidemathis Simon, 1903 are described from Luzon Island, Philippines. Lepidemathis cavinti $\mathrm{n}$. sp. is from the primary forest in Cavinti, Laguna province; Lepidemathis dogmai $\mathrm{n}$. $\mathrm{sp}$. is from the boulder in a dry river in Mauban, Quezon province; and Lepidemathis lipa $\mathrm{n}$. sp. is from bamboo trees near a young cacao orchard in Lipa City, Batangas province. Photographs are provided to facilitate species identification.
\end{abstract}

Keywords: Araneae, Salticidae, Lepidemathis cavinti n. sp., Lepidemathis dogmai n. sp., Lepidemathis lipa n. sp., Luzon Island, Philippines

\section{Introduction}

Jumping spiders belonging to order Araneae are common invertebrates present in both agricultural and natural ecosystems worldwide. They have the characteristic presence of large and conspicuous anterior median eyes (AME) providing telescopic vision (Koh and Ming, 2014) to effectively hunt for preys and the jumping habit of this spider family are two unique diagnostic characteristics that distinguish the group from other families of spiders.

Presently, there is paucity of taxonomic knowledge on the jumping spiders or Salticidae of the Philippines; Barrion and Litsinger (1995) taxonomically recognized 36 species under 20 genera. Later on, Bavia gabrieli Barrion and Neobrettus nangalisagus Barrion were added to the checklist of Philippine spiders (Barrion et.al.,2002). Quite recently, Frendenschuss and Seiter (2016) added four species, namely, Agorius marieae

\footnotetext{
${ }^{1}$ Environmental Biology Division, Institute of Biological Sciences, and ${ }^{2}$ Museum of Natural History, University of the Philippines Los Banos, 4031, Laguna, Philippines

${ }^{3}$ Biological Control Research Unit, Biology Department, College of Science, De LaSalle University, Taft Manila, Philippines and Adjunct Curator of Spiders, Parasitic Hymenoptera and Rice Arthropods, Museum of Natural History, University of the Philippines, Los Banos 4031, Laguna, Philippines.
}

*Corresponding email: abdupo@up.edu.ph

Date Submitted: 30 July 2019

Date Accepted: 05 March 2020
Frendenschuss and Seiter, 2016, Cosmophasis lami Beatty and Prószyński 1997, Phaeacius hampi Freudenschuss and Seiter 2016, Epidelaxia maurerae Frendenschuss and Seiter, 2016, Gambaquezonia curioi Freudenschuss, Grabolle \& Krehenwinkel, 2016 and Lepidemathis luisae Frendenschuss and Seiter, 2016. There are currently 100 salticid species recorded in the country (World Spider Catalog, 2020). Below is a checklist of all known Salticidae in the Philippines (Table 1).

In 2014, we participated in the animal biodiversity survey program of the University of the Philippines Museum of Natural History (UPLBMNH), University of the Philippines, Los Baños, Laguna conducted in Cavinti, Laguna province that overlaps with Mauban, Quezon province. We handled the Araneae group and among the collected samples are the Salticidae.

While running the taxonomic identification of the family, we found some interesting jumping spiders that possess a modified prolateral structure in the tibia of the male pedipalps. Careful examination revealed that it belongs to the genus Lepidemathis Simon, 1903 primarily known only from the Philippines. To date, only four species of Lepidemathis $-L$. sericea (Simon, 1899) [type-species]; L. haemorrhoidalis (Simon, 1899); L. unicolor (Karsch, 1880) and L. luisae Frendenschuss and Seiter, 2016 occur in the Philippines. In this paper, we report herewith three new species, namely, Lepidemathis cavinti $\mathrm{n}$. sp. collected from the primary forest in Cavinti, Laguna; Lepidemathis dogmai $\mathrm{n}$. sp. from the boulder in a dry river bank in Mauban, Quezon; and Lepidemathis lipa n. sp. from a young cacao orchard close to bamboos and Gmelina trees in Lipa City, Batangas. 
Table 1. Known Salticidae in the Philippines.

\begin{tabular}{|c|c|}
\hline Genus & Species \\
\hline \multirow{2}{*}{ Agorius Thorell, 1877} & Agorius marieae Freudenschuss \& Seiter, 2016 \\
\hline & Agorius semirufus Simon, 1901 \\
\hline \multirow{2}{*}{ Bavia Simon, 1877} & Bavia gabrieli Barrion, 2000 \\
\hline & Bavia intermedia (Karsch, 1880) \\
\hline \multirow{2}{*}{ Bocus Peckham \& Peckham, 1892} & Bocus excelsus Peckham \& Peckham, 1892 \\
\hline & Bocus philippinensis Wanless, 1978 \\
\hline Carrhotus Thorell, 1891 & Carrhotus barbatus (Karsch, 1880) \\
\hline \multirow{4}{*}{ Chalcotropis Simon, 1902} & Chalcotropis caeruleus (Karsch, 1880) \\
\hline & Chalcotropis decemstriata Simon, 1902 \\
\hline & Chalcotropis luceroi Barrion \& Litsinger, 1995 \\
\hline & Chalcotropis praeclara Simon, 1902 \\
\hline \multirow{4}{*}{ Cosmophasis Simon, 1901} & Cosmophasis estrellaensis Barrion \& Litsinger, 1995 \\
\hline & Cosmophasis lami Berry, Beatty \& Prószyński, 1997 \\
\hline & Cosmophasis parangpilota Barrion \& Litsinger, 1995 \\
\hline & Cosmophasis trioipina Barrion \& Litsinger, 1995 \\
\hline Cytaea Keyserling, 1882 & Cytaea sinuata (Doleschall, 1859) \\
\hline \multirow{3}{*}{ Emathis Simon, 1899} & Emathis astorgasensis Barrion \& Litsinger, 1995 \\
\hline & Emathis makilingensis Barrion \& Litsinger, 1995 \\
\hline & Emathis weyersi Simon, 1899 \\
\hline Emertonius Peckham \& Peckham, 1892 & Emertonius palawensis Prószyński, 2018 \\
\hline \multirow{2}{*}{ Epeus Peckham \& Peckham, 1886} & Epeus edwardsi Barrion \& Litsinger, 1995 \\
\hline & Epeus hawigalboguttatus Barrion \& Litsinger, 1995 \\
\hline Epidelaxia Simon, 1902 & Epidelaxia maurerae Freudenschuss \& Seiter, 2016 \\
\hline Ergane L. Koch, 1881 & Ergane carinata Berry, Beatty \& Prószyński, 1996 \\
\hline \multirow{3}{*}{ Gambaquezonia Barrion \& Litsinger, 1995} & Gambaquezonia curioi Freudenschuss, Grabolle \& Krehen- \\
\hline & winkel, 2016 \\
\hline & Gambaquezonia itimana Barrion \& Litsinger, 1995 \\
\hline Heratemita Strand, 1932 & Heratemita alboplagiata (Simon, 1899) \\
\hline \multirow{2}{*}{ Hyllus C. L. Koch, 1846} & Hyllus gulosus (Simon, 1877) \\
\hline & Hyllus maskaranus Barrion \& Litsinger, 1995 \\
\hline Lagnus L. Koch, 1879 & Lagnus edwardsi Zhang \& Maddison, 2012 \\
\hline \multirow{4}{*}{ Lepidemathis Simon, 1903} & Lepidemathis haemorrhoidalis (Simon, 1899) \\
\hline & Lepidemathis luisae Freudenschuss \& Seiter, 2016 \\
\hline & Lepidemathis sericea (Simon, 1899) \\
\hline & Lepidemathis unicolor (Karsch, 1880) \\
\hline Mantisatta Warburton, 1900 & Mantisatta longicauda Cutler \& Wanless, 1973 \\
\hline \multirow{11}{*}{ Myrmarachne MacLeay, 1839} & Myrmarachne assimilis Banks, 1930 \\
\hline & Myrmarachne attenuata (Karsch, 1880) \\
\hline & Myrmarachne bakeri Banks, 1930 \\
\hline & Myrmarachne bidentata Banks, 1930 \\
\hline & Myrmarachne biseratensis Badcock, 1918 \\
\hline & Myrmarachne caliraya Barrion \& Litsinger, 1995 \\
\hline & Myrmarachne chapmani Banks, 1930 \\
\hline & Myrmarachne corpuzrarosae Barrion, 1981 \\
\hline & Myrmarachne dubia (Peckham \& Peckham, 1892) \\
\hline & Myrmarachne edentula (Peckham \& Peckham, 1892) \\
\hline & Myrmarachne iridescens Banks, 1930 \\
\hline
\end{tabular}


Table 1 (continued). Known Salticidae in the Philippines.

\begin{tabular}{|c|c|}
\hline Myrmarachne MacLeay, 1839 & $\begin{array}{l}\text { Myrmarachne markaha Barrion \& Litsinger, } 1995 \\
\text { Myrmarachne mcgregori Banks, } 193 \\
\text { Myrmarachne nigella Simon, 1901 } \\
\text { Myrmarachne onceana Barrion \& Litsinger, } 1995 \\
\text { Myrmarachne opaca } \text { (Karsch, 1880) } \\
\text { Myrmarachne piercei Banks, } 1930 \\
\text { Myrmarachne pinakapalea Barrion \& Litsinger, } 1995 \\
\text { Myrmarachne pinoysorum Barrion \& Litsinger, } 1995 \\
\text { Myrmarachne seriatis Banks, } 1930 \\
\text { Myrmarachne tagalica Banks, } 1930 \\
\text { Myrmarachne tayabasana Chamberlin, } 1925 \\
\text { Myrmarachne vulgarisa } \text { Barrion \& Litsinger, } 1995\end{array}$ \\
\hline Nannenus Simon, 1902 & Nannenus constrictus (Karsch, 1880) \\
\hline Neobrettus Wanless, 1984 & Neobrettus nangalisagus Barrion, 2001 \\
\hline Orthrus Simon, 1900 & $\begin{array}{l}\text { Orthrus bicolor Simon, } 1900 \\
\text { Orthrus calilungae Barrion, } 1998 \\
\text { Orthrus palawanensis Wanless, } 1980\end{array}$ \\
\hline Pancorius Simon, 1902 & Pancorius curtus (Simon, 1877) \\
\hline Panysinus Simon, 1901 & Panysinus semiargenteus (Simon, 1877) \\
\hline Phaeacius Simon, 1900 & $\begin{array}{l}\text { Phaeacius alabangensis Wijesinghe, } 1991 \\
\text { Phaeacius canalis Wanless, } 1981 \\
\text { Phaeacius hampi Freudenschuss \& Seiter, } 2016 \\
\text { Phaeacius leytensis Wijesinghe, } 1991 \\
\text { Phaeacius mainitensis Barrion \& Litsinger, } 1995\end{array}$ \\
\hline Philates Simon, 1900 & Philates grammicus Simon, 1900 \\
\hline Phintella Strand, 1906 & $\begin{array}{l}\text { Phintella bunyiae Barrion \& Litsinger, } 1995 \\
\text { Phintella piatensis Barrion \& Litsinger, } 1995 \\
\text { Phintella vittata (C. L. Koch, 1846) }\end{array}$ \\
\hline Plexippus C. L. Koch, 1846 & $\begin{array}{l}\text { Plexippus petersi (Karsch, 1878) } \\
\text { Plexippus paykulli (Audouin, 1826) }\end{array}$ \\
\hline Portia Karsch, 1878 & Portia labiata (Thorell, 1887) \\
\hline Psenuc Prószyński, 2016 & $\begin{array}{l}\text { Psenuc manillaensis (Prószyński, 1992) } \\
\text { Psenuc vesporum (Prószyński, 1992) }\end{array}$ \\
\hline Rhene Thorell, 1869 & $\begin{array}{l}\text { Rhene deplanata (Karsch, 1880) } \\
\text { Rhene habahumpa Barrion \& Litsinger, } 1995 \\
\text { Rhene hinlalakea } \text { Barrion \& Litsinger, } 1995\end{array}$ \\
\hline Rogmocrypta Simon, 1900 & Rogmocrypta nigella Simon, 1900 \\
\hline Siler Simon, 1889 & Siler semiglaucus (Simon, 1901) \\
\hline Simaetha Thorell, 1881 & $\begin{array}{l}\text { Simaetha damongpalaya Barrion \& Litsinger, } 1995 \\
\text { Simaetha makinanga Barrion \& Litsinger, } 1995\end{array}$ \\
\hline Spartaeus Thorell, 1891 & Spartaeus uplandicus Barrion \& Litsinger, 1995 \\
\hline Stertinius Simon, 1890 & Stertinius pilipes Simon, 1902 \\
\hline Telamonia Thorell, 1887 & $\begin{array}{l}\text { Telamonia cristata Peckham \& Peckham, } 1907 \\
\text { Telamonia jolensis (Simon, 1902) } \\
\text { Telamonia livida (Karsch, 1880) } \\
\text { Telamonia masinloc Barrion \& Litsinger, } 1995 \\
\text { Telamonia parangfestiva Barrion \& Litsinger, } 1995 \\
\text { Telamonia setosa (Karsch, 1880) }\end{array}$ \\
\hline
\end{tabular}


Table 1 (continued). Known Salticidae in the Philippines.

Thiania coelestis (Karsch, 1880)

Thiania latefasciata (Simon, 1877)

Thiania C. L. Koch, 1846

Thiania simplicissima (Karsch, 1880)

Thiania viscaensis Barrion \& Litsinger, 1995

\begin{tabular}{lll}
\hline Thyene & Simon, 1885 & Thyene manipisa (Barrion \& Litsinger, 1995) \\
\hline Toxeus & C. L. Koch, 1846 & Toxeus maxillosus C. L. Koch, 1846 \\
\hline
\end{tabular}

\section{Materials and Methods}

The main collection site is Cavinti, Laguna where its remarkable church-like to dome-shaped limestone caves, undulating terrain with a clear fresh water running from its river coming from the top of the mountain covered with primary forest on the top, secondary forest growth in the mid-elevation and slash-and burn farms with bananas and coconut trees in the lowlands just above the river banks have attracted many naturelovers. The water from this site supplies the Pagsanjan Rapid Falls, a famous tourism destination in Laguna province. The inner part of Cavinti municipality overlaps with Mauban, Quezon still teeming with a combination of primary and secondary forest cover but the boundary has a dry river bank with lots of boulders (Figure 1). The collection from Marauoy, Lipa City, Batangas came from a young cacao orchard close to Gmelina and bamboo trees.

Beating method using a $1-\mathrm{x}-1 \mathrm{~m}^{2}$ jute sack cloth with a cross stick in the middle and visual vial-tapping were used in the field collection of jumping spiders. The collected samples were kept in clear plastic tubes $60 \mathrm{~mm}$ high and $20 \mathrm{~mm}$ in diameter and preserved in $70 \%$ ethyl alcohol. Each tube is provided with collection labels, namely, country/province/ municipality/district or barangay/GPS coordinates of collection site; habitat/collector/date of collection and the collection

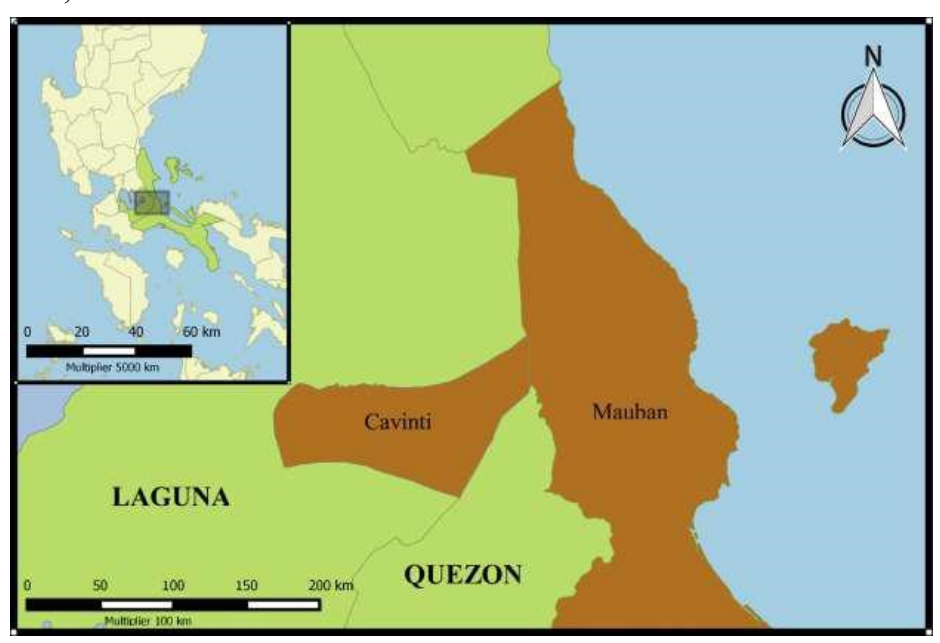

Figure 1. Map of the main collection site, Cavinti, Laguna. number.

Spiders were examined under a Nikon SMZ 445 and magnification was increased by adding a Nikon $1.5 \mathrm{X}$ magnifier. Images were taken via a mounted Accu-Scope 5.0 Mega-pixel Excellis HD color microscopy camera CAT\# AU-300-HD to a Leica A60 S stereo microscope.

All voucher specimens used in the study are deposited in the Arachnological Collection of the University of the Philippines Museum of Natural History (UPLBMNH), UP Los Baños, College, Laguna 4030. Measurements were taken using an ocular micrometer and are in millimetres $(\mathrm{mm})$. Leg measurements are as follows: total length (length of femur, length of patella + tibia, length of metatarsus, length of tarsus). Spination [dvpr]: dorsal (d), ventral (v), prolateral (p) and retrolateral (r). Abbreviations follow Barrion and Litsinger (1995) used in this paper include: $\mathrm{AER}=$ anterior eye row; $\mathrm{PER}=$ posterior eye row; $\mathrm{AME}=$ anterior median eyes; $\mathrm{ALE}=$ anterior lateral eyes; $\mathrm{PME}=$ posterior median eyes; $\mathrm{PLE}=$ posterior lateral eyes; $\mathrm{MOQ}=$ median ocular quadrangle; $\mathrm{CL}=$ carapace length; $\mathrm{CW}=$ carapace width; $\mathrm{AbL}=$ abdominal length; $\mathrm{AbW}=$ abdominal width; $\mathrm{RTA}=$ retrolateral tibial apophysis; $\mathrm{mm}=$ millimetres.

\section{Species Accounts}

Genus Lepidemathis Simon, 1903 [type species: Lepidemathis sericea Simon,1899]

Lepidemathis cavinti n. sp. [ Figures 2 to 4]

Holotype male: Total length 7.60. CL 3.65, CW 2.50; AbL 3.90, AbW 1.90mm.

Carapace. Brownish orange lined with a thin mat of creeping white hairs in the posterior cephalic and entire thoracic area. Median posterior eye area to hind portion of MOQ lined with a small mat of immaculate white hairs forming a Y-band similar to the hairs surrounding PME. AME surrounded by a thick mat of orange red hairs. Chelicerae brown red, vertical and flat dorsally but roughened by transverse ridges anteriorly, its inner lateral margins with 10 to 16 relatively long white hairs. 

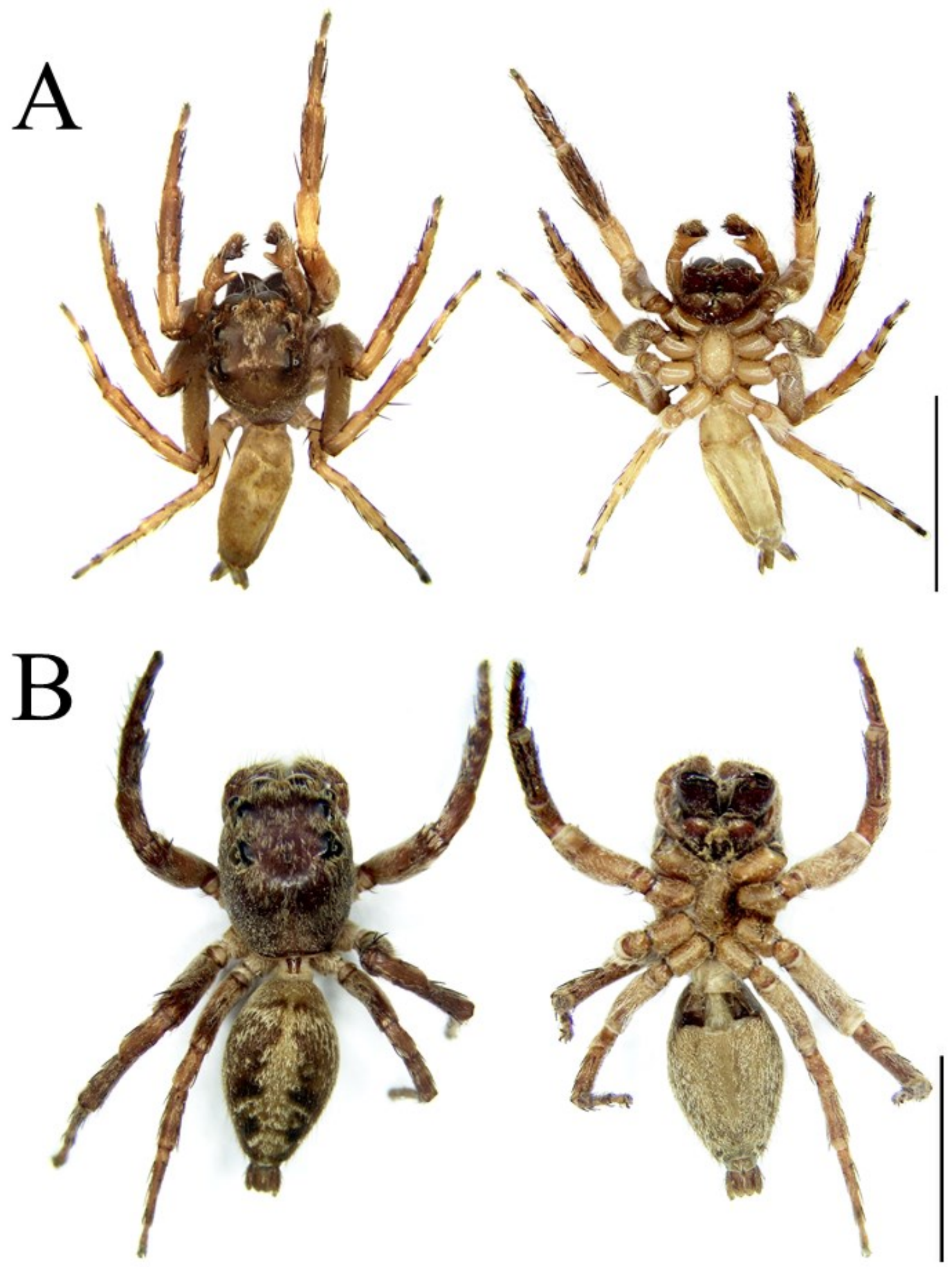

Figure 2. Lepidemathis cavinti $\mathrm{n}$. sp. habitus; dorsal and ventral views of the male (A); dorsal and ventral views of the female (B). < scale bars: $5 \mathrm{~mm}>$. 


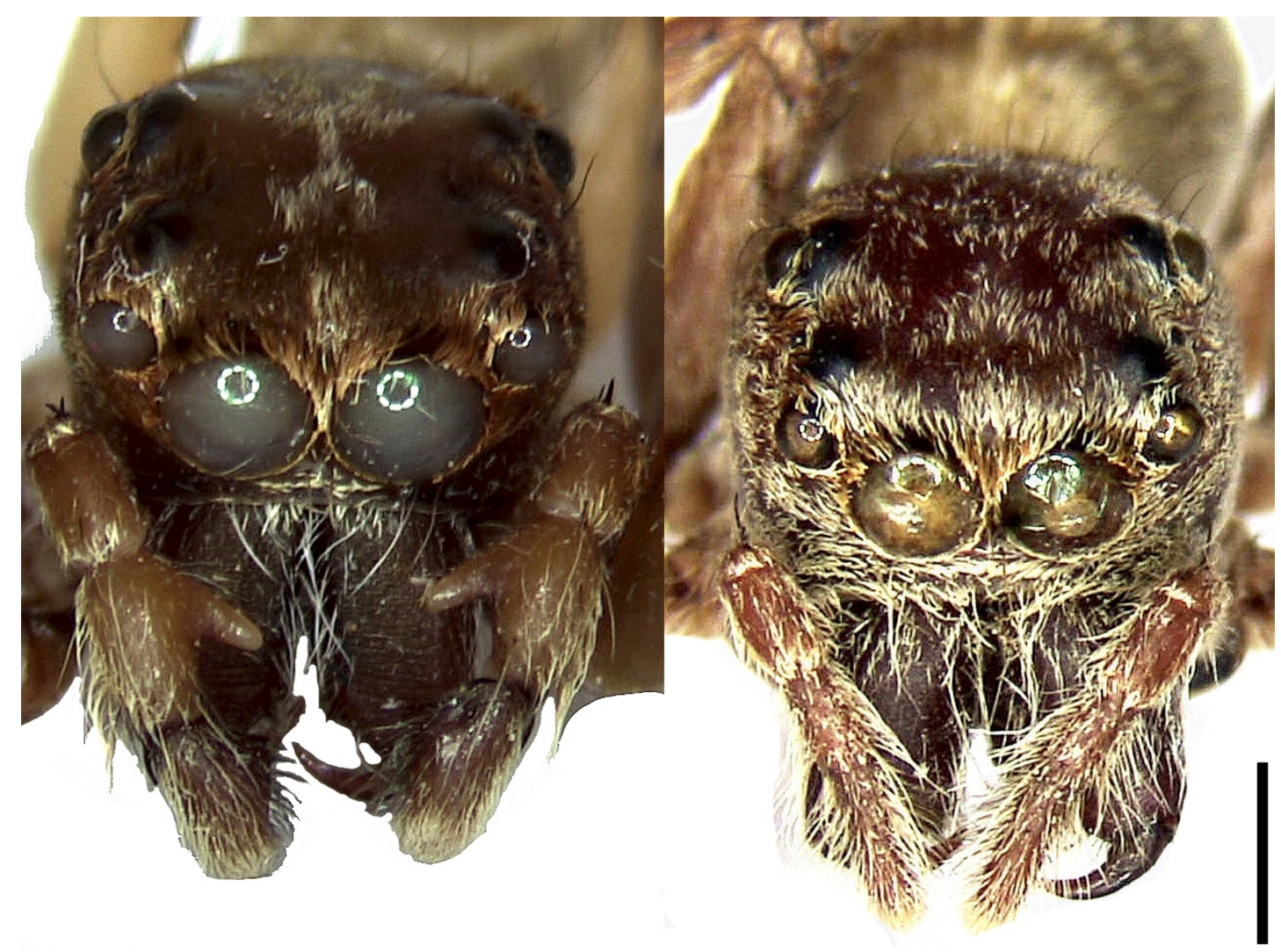

Figure 3. Lepidemathis cavinti n. sp. cephalothorax, frontal view: male (left); female (right). $<$ scale bar: $1 \mathrm{~mm}>$.
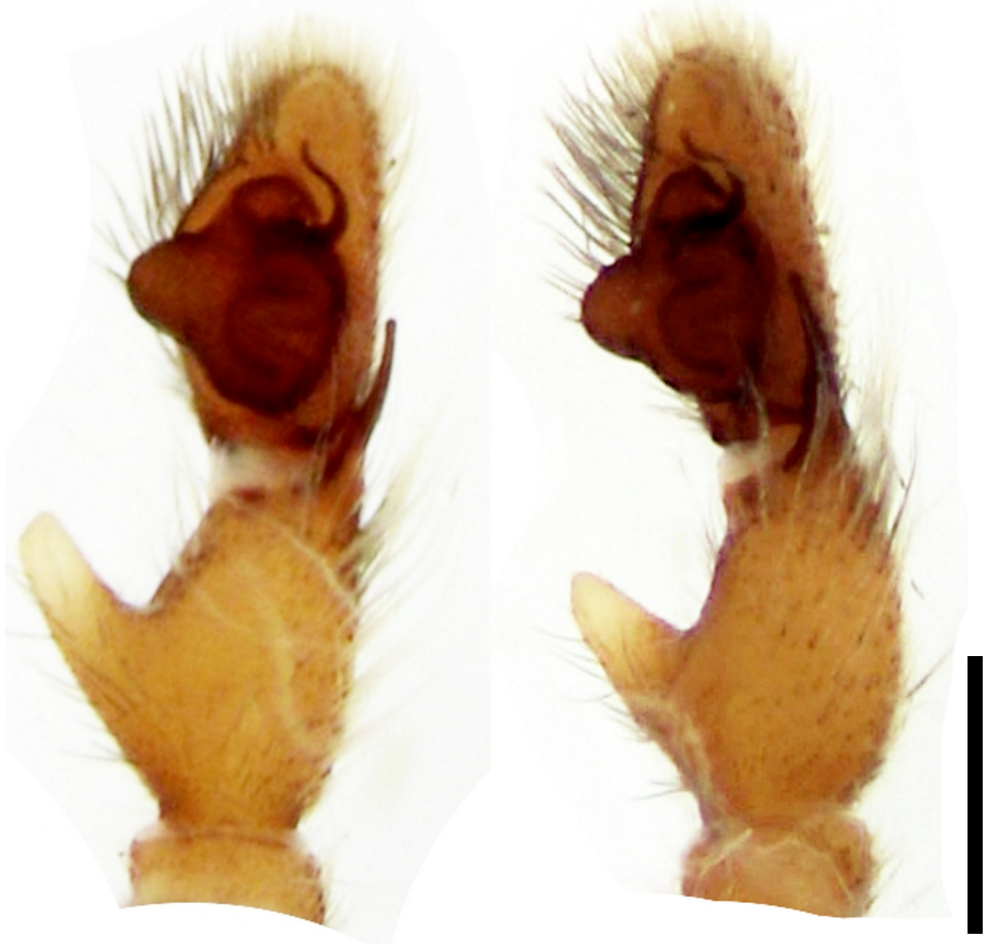

Figure 4. Lepidemathis cavinti n. sp. left pedipalp in frontal (left) and retrolateral (right) views. <scale bar: $1 \mathrm{~mm}>$. 
The basal inner area of chelicerae bears short white clubbed hairs. Promargin bears two teeth, a large apical and a small basal tooth. Retromargin bears five teeth in decreasing order in size from the large T1 to the smallest T5. Maxillae 1.67x longer than wide $(1.16: 0.69 \mathrm{~mm})$, broadly rounded apicolaterally and has a groove in mid-inner margins accommodating the laterally expanded labium. Serrula with golden yellow to silvery hairs mostly short except the very long set on the apical end. Labium $1.66 \mathrm{x}$ longer than wide $(0.80: 0.50 \mathrm{~mm})$. Midbasal half of labium bears long white hairs. Sternum yellow 1.76x longer than wide $(1.50: 0.85 \mathrm{~mm})$, apically truncate, subparallel-sided, slightly concave opposite coxa IV and narrowly truncate posteriorly. Median area of sternum lined with short white converging hairs, and long silvery white erect hairs laterally.

Eyes. PLE row length (2.45) > AER row length (2.35) > PME row length $(1.67 \mathrm{~mm})$. Eye diameter $(\mathrm{mm})$ : AME right $(0.82)>$ AME left $(0.76)>$ ALE $=$ PLE $(0.44)>$ PME (0.11). Eye distance $(\mathrm{mm})$ : PME-PME (2.08) > PLE-PLE (2.00) > AME-ALE (0.13) > AME-AME (0.07). Clypeus height 0.25 AME diameter, middle area with a pair of brown porrect long setae, and short white club setae and three long white hairs each below AME that are converging.

Legs. Yellow brown with strong dark brown spines. Spination in femora I-IV: I 3-0-2-2; II 3-0-3-3; III 3-0-3-1; IV 3 -0-0-1. Tibiae I-IV: I 1-6-3-1; II 1-5-3-1; III 1-3-1-3 and IV 0-3 -3-3, dorsal apical area with a long hair. Metatarsi I-IV: I 0-0-34; II 0-0-4-4; III 0-4-3-2 and IV 0-4-4-3. Leg formula 3124.

Abdomen. Uniformly light-yellow brown dorsally, anteriorly broad and pointed posteriorly with an orange red markings subposterodorsally. Venter uniformly pale yellowish brown. Posterior spinnerets slender, $0.60 \mathrm{~mm}$ long, $0.15 \mathrm{~mm}$ wide and slightly longer to the more robust anterior pair measuring $0.50 \mathrm{~mm}$ long and $0.30 \mathrm{~mm}$ wide.

Pedipalp. With a long tibial prolateral outgrowth at $45^{\circ}$ angle, the outgrowth is as long as the apical width of tibia and its rounded tip is yellow. Tegulum strongly bulge prolaterally. Embolus short, its base at $12{ }^{0}$ clock coiling C-shaped to 3 $0^{\prime}$ clock with its tip directed back to $12{ }^{0^{\prime}}$ clock. Prolateral side of cymbium lined with relatively long and thick dark brown hairs. RTA dark brown, long and straight running parallel to the cymbium.

Paratype female. Total length $10.20 \mathrm{~mm}$. CL $4.40 \mathrm{~mm}$, CW $3.20 \mathrm{~mm}$. AbL $5.50 \mathrm{~mm}$, AbW $2.80 \mathrm{~mm}$. Carapace dark brown covered with short white hairs, black eye margins and golden yellow brown hairs lined the posterior of AER in a transverse row. A dark brown bulge present in the inner area of ALE and PME. Fovea relatively long and shallow located almost between PLE. Circular margins of AME ringed with orange hairs. Clypeal area with short and long white hairs, middle part of clypeus lined with a transverse row of relatively long clubbed hairs located below AME with tips converging towards each other. Chelicerae dark reddish brown clothed with long white hairs basoprolaterally, smooth dorsally but bear fine transverse ridges medially and subposteriorly. Promargin bears two teeth with T1 > T2. Retromargin bears five teeth and has a rebordered basal margin. Maxillae brown at the narrowed basal three-fourths and yellow at the broadened apical one-fourth. Labium dark reddish brown, longer than wide, and longitudinally ridge-like in the middle. Sternum brown longer than wide, hirsute and truncate apically but pointed posteriorly. Eye row length $(\mathrm{mm})$ : PLER (2.83) > AER (2.67) > PMER (2.45). Eye diameter $(\mathrm{mm})$ : AME $(0.87)>\operatorname{ALE}(0.49)>$ PLE (0.44) > PME (0.12). Eye separation (mm): PME-PME (2.27) > PLE-PLE (2.20) > ALE-AME (0.17) > AME-AME (0.07). Clypeus height 0.33 AME diameter. Legs uniformly brown and bear strong spines. Leg III > II > IV. Leg I both missing.

Abdomen ovoid, yellowish brown with submarginal irregular patches of 6 to 7 brownish black markings. Venter yellow with a pair of longitudinal grooves. Spinnerets brown and visible dorsally, anterior and posterior pairs both distinctly longer than wide. Epigynum dome-shaped with a pair of large anterior windows or fossae, and a pale brown longitudinal line. Fertilization duct with three to four coils. Spermathecae relatively small.

Table 2. Lepidemathis cavinti n. sp. leg measurements (mm).

\begin{tabular}{cccccc}
\hline Leg & Femur & Patella + Tibia & Metatarsus & Tarsus & Total \\
\hline I & $2.35 /-$ & $3.80 /-$ & $1.45 /-$ & $0.70 /-$ & $8.30 /-$ \\
II & $2.30 / 2.50$ & $3.10 / 3.00$ & $1.35 / 1.30$ & $0.65 / 0.70$ & $7.40 / 7.50$ \\
III & $3.10 / 2.85$ & $3.00 / 3.20$ & $2.00 / 1.80$ & $1.00 / 1.40$ & $9.10 / 9.25$ \\
IV & $2.40 / 2.40$ & $2.45 / 2.60$ & $1.60 / 1.70$ & $0.85 / 0.70$ & $7.30 / 7.40$ \\
\hline
\end{tabular}


Material examined. PHILIPPINES, Laguna province, Cavinti, Cavinti Park designated tourism area, $14^{\circ} 14^{\prime} 57.6^{\prime \prime} \mathrm{N}$ 121 30'20.7"E, holotype male (ARA MC034), extracted through vial tapping from the trunk of a dipterocarp tree about $1.7 \mathrm{~m}$ from the ground with about a meter tree trunk diameter, May 22-27, 2014; paratype male (ARA MC207) and paratype female (ARA MC208), same data as holotype.

Etymology: The specific epithet is named after the type locality.

Diagnosis: This species is separated from Lepidemathis dogmai $\mathrm{n}$. sp. (ARA MC286) by the longer and more robust prolateral process in the pedipalp's tibia positioned at $45^{\circ}$ angle, more orange brown body without three pairs of gray bands in the thoracic area, and its presence only in primary forest habitat. It differs from all Lepidemathis species in having a more pronounced and robust prolateral tibial process arising at $45^{\circ}$ angle. The palp of $L$. cavinti palp resembles $L$. luisae in the prominent, narrow and relatively sharp retrolateral apophysis and a well pronounced prolateral outgrowth but differs from the latter by exhibiting only one non-sclerotized prolateral tibial apophysis at the palp's tibial swelling, compared to L. luisae's two non-sclerotized apophyses - one huge, blunt, and elongated apophysis very slightly curved along its retrolateral edge; and a much smaller, relatively truncate apophysis. Also, L. cavinti's sole tibial apophysis is basally wider, shorter, straighter, and much blunder/rounded at the apex.

Lepidemathis dogmai n. sp. [ Figures 5 to 7]

Holotype male. Total length 7.80. CL 3.60, CW 2.70. AbL 4.20, AbW 2.10.

Carapace. uniformly dark reddish brown except black and swollen eye margins of PME-ALE and PLE. Surrounds of AE (AME + ALE) ringed with yellow to orange red hairs. Cephalic dorsum smooth, laterals and thoracic area clothed with short white hairs. Fovea black, short and shallow. Chelicerae glossy dark red, lined prolaterally with long white hairs, retrolaterally with shorter white hairs and entirely rough dorsally decorated with fine transverse ridges. Length of chelicerae as long as the distance from AME to AME Maxillae reddish brown, mushroom button-like anteriorly with whitish and smooth base of serrula, narrow basal part with a finely punctuated median part. Labium about $1.3 \mathrm{x}$ longer than width and elevated median area finely punctuated. Sternum yellowish brown and moderately hairy.

Eyes. PER length (2.50) > AER (2.35) > PMER (2.20). Eye diameter: AME (0.75) > ALE (0.40) > PLE (0.35) > PME $(0.10)$. Eye margins ringed with orange brown hairs. Clypeus height $0.53 \mathrm{x}$ AME diameter, lined with four white hairs.

Legs. brownish red with darker femora and strong spines. Legs I and II stronger than III and IV. Venter of femur IV with long white hairs. Coxae and trochanter reddish brown in legs I and II but yellowish brown in III and IV. Spination in femur I 40-1-1, II 4-0-3-3, III 4-0-0-3 and IV 4-0-0-0. Tibia I and II 1-6-3 -3, III 1-3-3-3 and IV 1-4-3-3. Metatarsi I to IV each with 0-4-22. Leg formula 1324.

Abdomen. Oblongate, brownish yellow and with a pair of rounded black sigilla at midlength. Venter uniformly dull brown except anterior one-fourth with dark red brown book lungs divided by two longitudinal yellow lines.

Pedipalp. With moderately long and sigmoid RTA having a slightly rounded tip that runs parallel with the cymbium. Tibia with a small prolateroventral apophysis at about $45^{\circ}$ angle, its tip narrowly pointed. Base of embolus forms an apophysis, embolus directed at 100 'clock and it coils counter clockwise with the tip landing transversely at 120 'clock. Tegulum tip triangularly pointed. Sperm duct double-coiled and M-like. Base of subtegulum truncate viewed ventrally.

Material Examined. Philippines, Luzon Island, Quezon Province, Mauban, $14^{\circ} 11^{\prime} 07.4^{\prime \prime} \mathrm{N} 121^{\circ} 42^{\prime} 57.5^{\prime \prime} \mathrm{E}$, holotype male (MC452) extracted from Taro leaf overhanging the dry river bank, 22-27 May 2014, ATBarrion.

Etymology. The species is dedicated to an outstanding microbiologist, Dr. Irineo Dogma Jr.

Diagnosis. Runs close to Lepidemathis sericea in terms of RTA shape but distinctly differs from the latter in terms of the

Table 3. Lepidemathis dogmai $\mathrm{n}$. sp. leg measurements(mm).

\begin{tabular}{cccccc}
\hline Leg & Femur & Patella + Tibia & Metatarsus & Tarsus & Total \\
\hline I & 2.80 & 3.90 & 1.80 & 0.95 & 9.45 \\
II & 2.30 & 3.00 & 1.40 & 0.75 & 7.45 \\
III & 3.10 & 2.90 & 1.90 & 0.80 & 8.70 \\
IV & 2.10 & 2.40 & 1.70 & 0.80 & 7.00 \\
Pedipalp & 1.40 & 1.10 & - & 1.10 & 3.60 \\
\hline
\end{tabular}




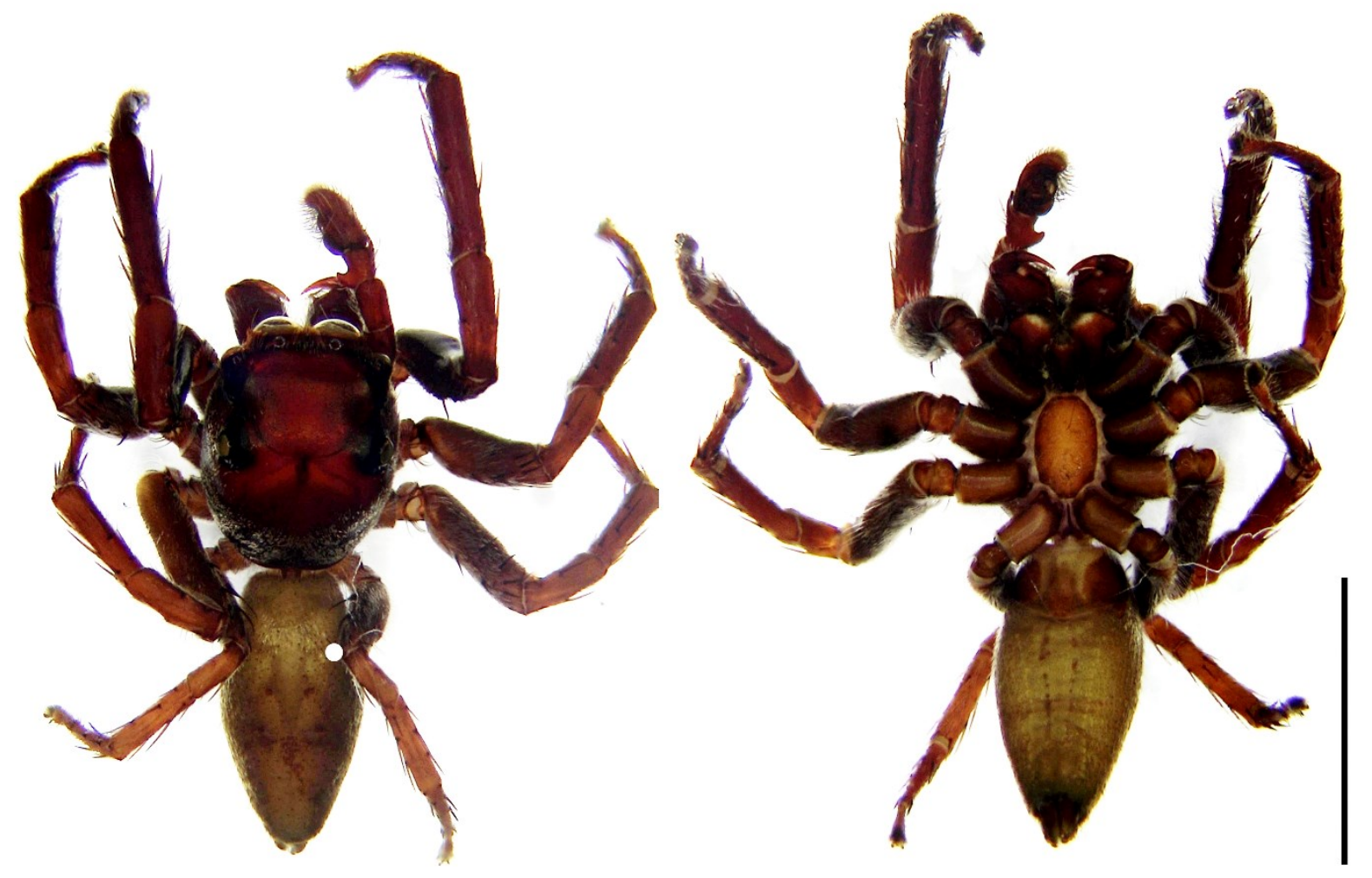

Figure 5. Lepidemathis dogmai $\mathrm{n}$. sp. habitus; dorsal (left) and ventral (right) views. $<$ scale bar: $5 \mathrm{~mm}>$.

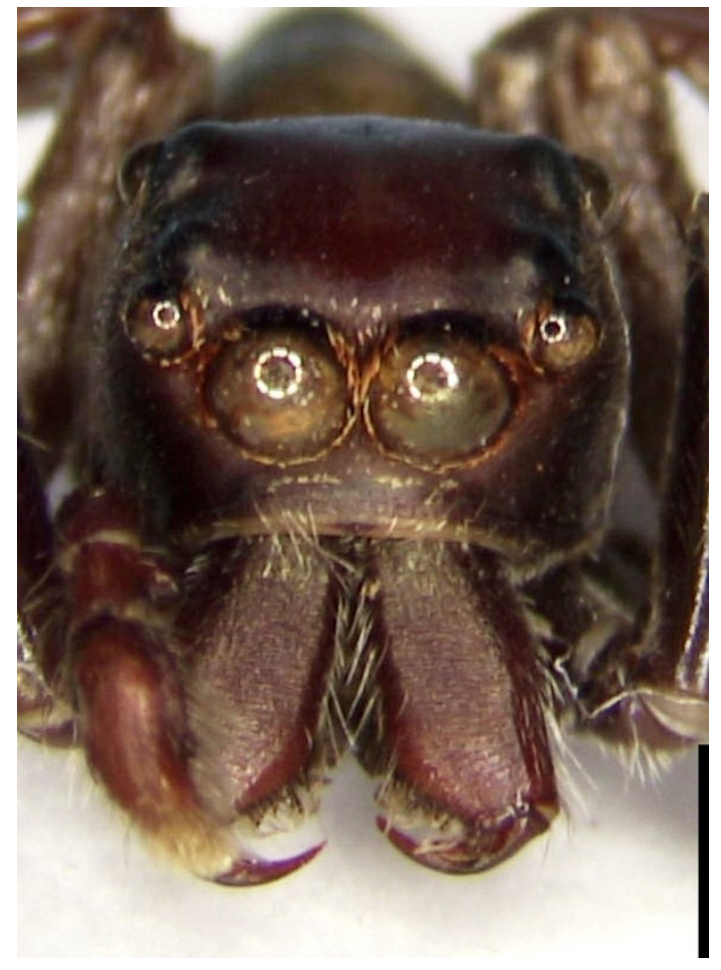

Figure 6. Lepidemathis dogmai n. sp. cephalothorax, frontal view. <scale bar: $1 \mathrm{~mm}>$.
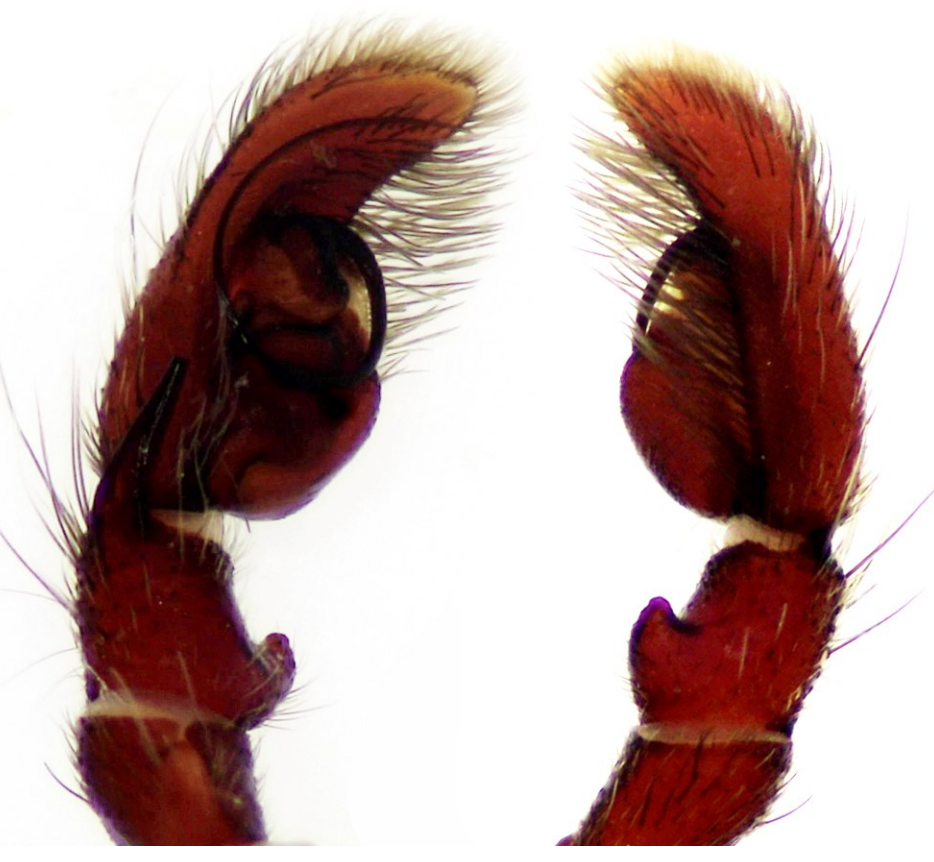

Figure 7. Lepidemathis dogmai n. sp. right pedipalp in retrolateral (left) and prolateral (right) views. <scale bar: $1 \mathrm{~mm}>$. 

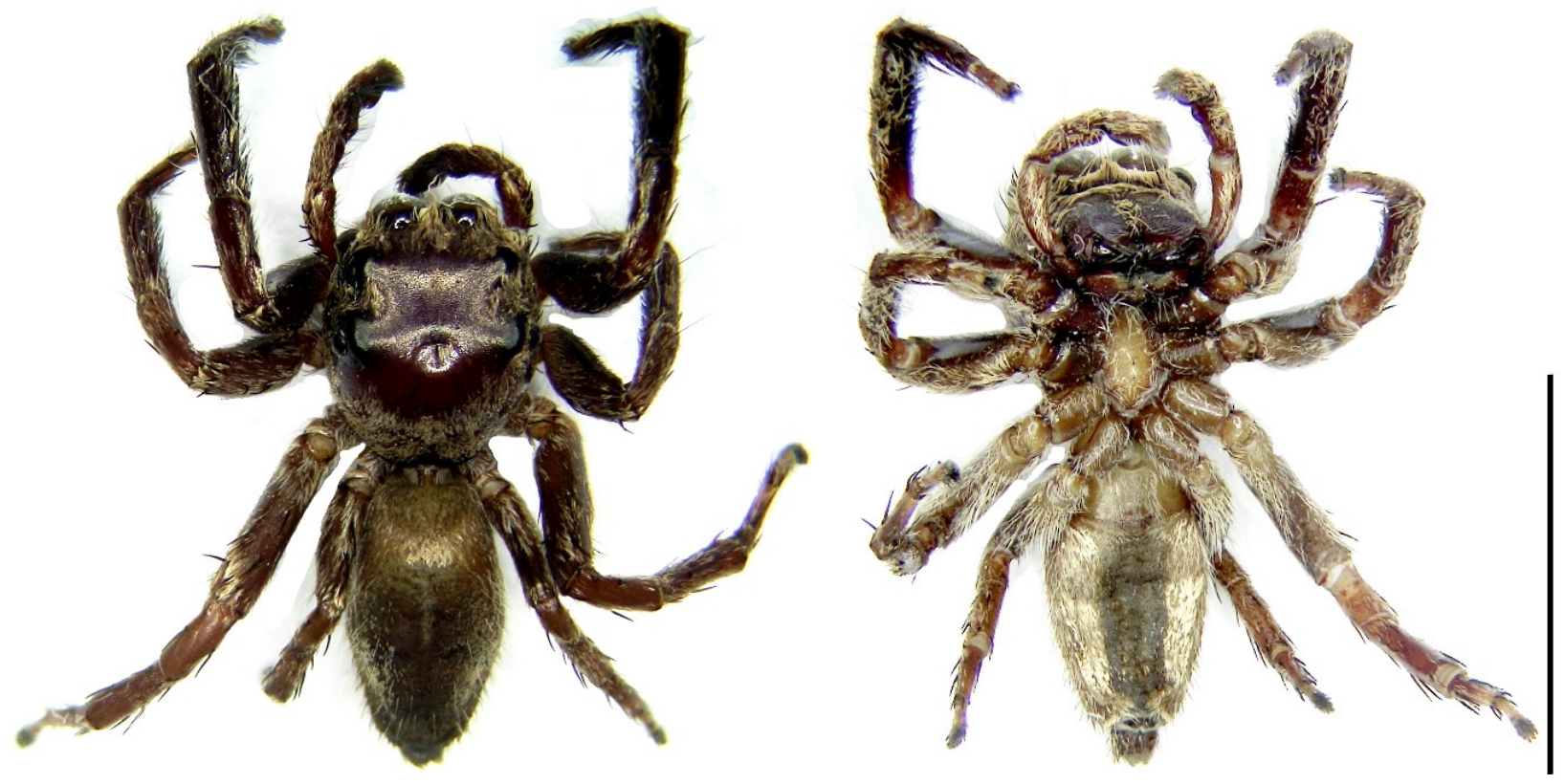

Figure 8. Lepidemathis lipa $\mathrm{n}$. sp. habitus; dorsal (left) and ventral (right) views. <scale bar: $5 \mathrm{~mm}>$.

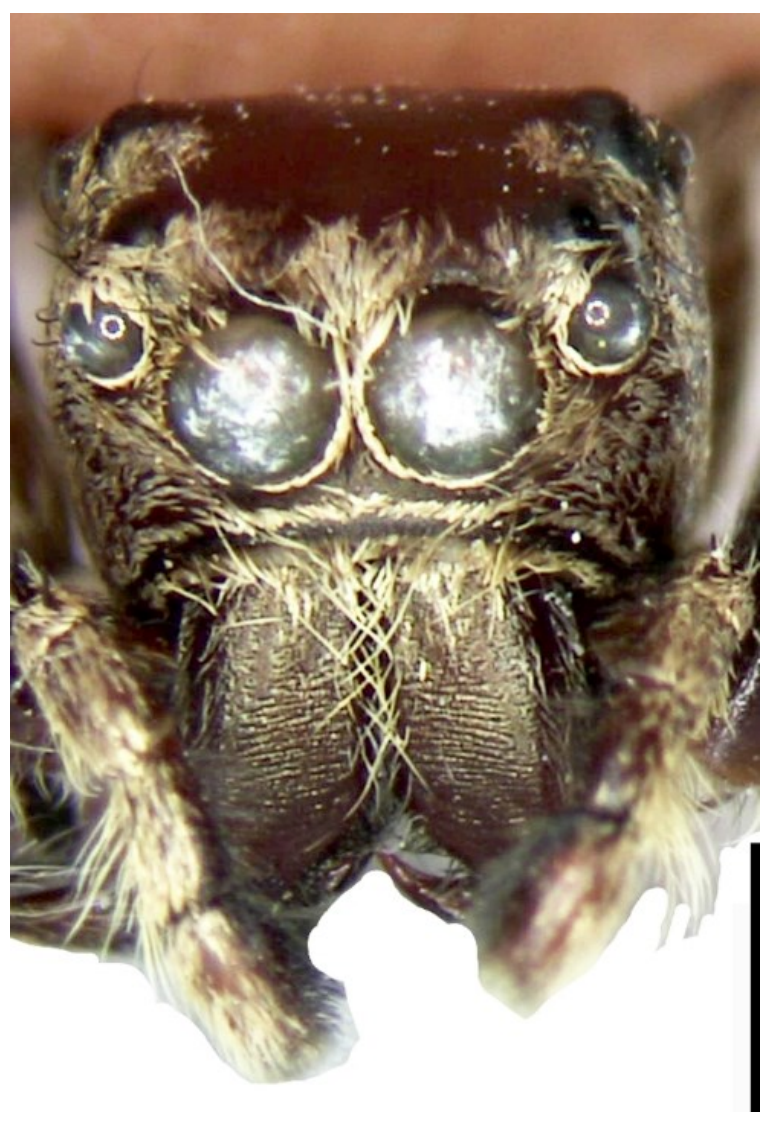

Figure 9. Lepidemathis lipa $\mathrm{n}$. sp. cephalothorax, frontal view. <scale bar: $1 \mathrm{~mm}>$.
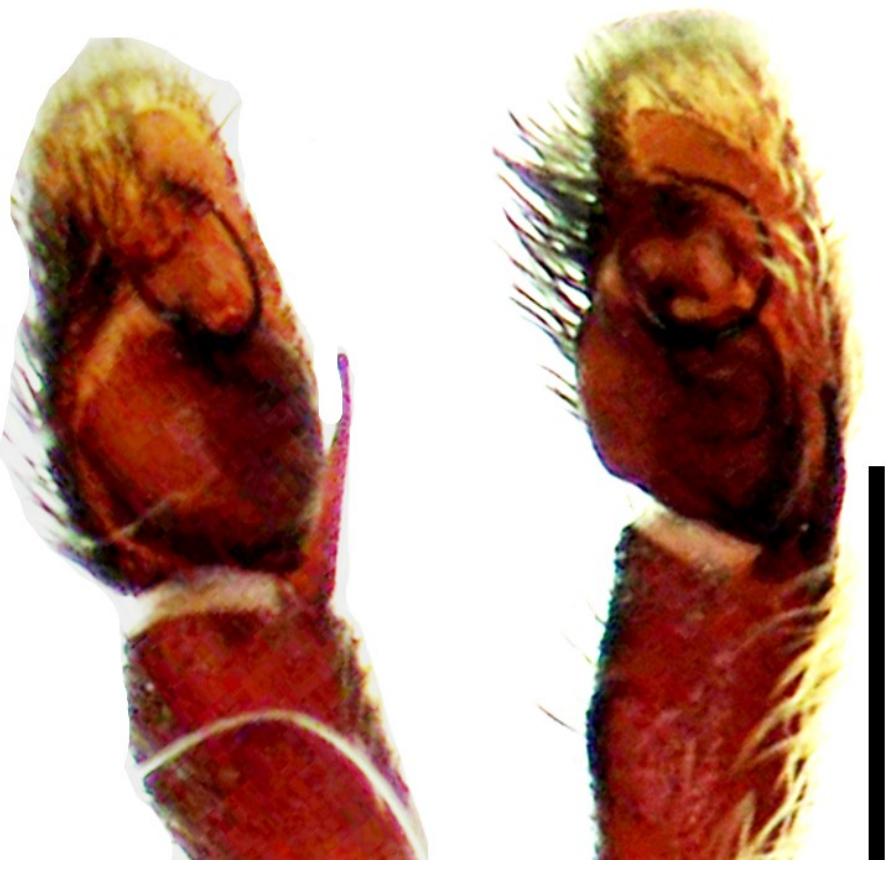

Figure 10. Lepidemathis lipa $\mathrm{n}$. sp. left pedipalp in frontal (left) and retrolateral (right) views. <scale bar: $1 \mathrm{~mm}>$. 
Table 4. Lepidemathis lipa $\mathrm{n}$. sp. leg measurements (mm).

\begin{tabular}{cccccc}
\hline Leg & Femur & Patella + Tibia & Metatarsus & Tarsus & Total \\
\hline I & 2.00 & 3.20 & 1.50 & 0.65 & 7.35 \\
II & 1.75 & 2.50 & 1.20 & 0.55 & 6.00 \\
III & 2.65 & 2.60 & 1.60 & 0.65 & 7.50 \\
IV & 1.80 & 1.80 & 1.40 & 0.55 & 5.55 \\
Pedipalp & 1.20 & 1.05 & - & 0.75 & 3.00 \\
\hline
\end{tabular}

following (a) point of origin of the much longer embolus; (b) swollen base of embolus apophysis-like, (c) shape of ventrolateral apophysis at $45^{\circ}$ angle, (d) truncate base of subtegulum, and (e) triangular tip tegulum.

\section{Lepidemathis lipa n. sp. [Figures 8 to 10]}

Holotype male: Total length 7.80. CL 3.60, CW 2.70. AbL 4.00, AbW 2.00.

Carapace. Blackish brown in the cephalic and dark reddish brown in the sloped thoracic area. Entire carapace covered with white lanceolate hairs. Eye area covered with pale brownish white hairs dorsally, margins of AME lined with dull white and light brown hairs. Distance between eyes with around nine long black hairs between AME to PME, three between PME and PLE, and two hairs behind PLE. Bulge present behind the inner corner of ALE and PME and inner margins of PLE. Fovea short and shallow. Clypeus lined with two transverse rows of converging hairs, median row short and white while the submedian row has long and short combination of hairs. Chelicerae dark reddish brown, dorsal surface roughly lined with transverse ridges, prolaterals with very short fine hairs but longer ones present subapically and much longer white hairs retrolaterally. Maxillae reddish brown, wider apically and narrow basally, serrula with black hairs and apically converging. Labium dark reddish brown, $2 \mathrm{x}$ longer than wide (0.80:0.40). Basal half of maxillae and labium with long white erect hairs. Sternum yellow, smooth except margins with white hairs, anterior and posterior ends truncate.

Eyes. Eye row length PLER (2.65) > AER (2.40) > PMER (2.20). Eye diameter: AME (0.70) > ALE (0.40) > PLE (0.35) $>$ PME (0.15). Clypeus height about half AME diameter.

Legs. Dark reddish brown, clothed with white hairs and strong lateral, ventral and dorsal spines. Spination in femur I 40-1-1, II 5-0-1-2, III 5-0-2-0, IV 4-0-0-0; tibial spination: I 1-62-3, II 1-6-3-3, III 1-4-2-2, IV 1-3-3-3; metatarsus I 0-4-2-2, II 0-2-3-3, III 3-5-2-2, IV 1-5-3-3. Leg formula 3124.
Abdomen. Oblongate, widest at midlength, brownish yellow clothed with creeping lanceolate white hairs anteriorly and short club to lanceolate hairs covering the posterior twothirds of abdomen. Venter with a broad reddish-brown longitudinal band and a pair of ovoid yellowish spot between the book lung cover. Lateral margins of abdomen with creeping silvery white white lanceolate hairs. Spinnerets black with apices of anterior pair converging apically and apices of posterior pair slightly diverging.

Pedipalp. Clothed with white hairs, tibia prolateroventrally with a small elongate tubercle. RTA long with a small rounded tip. Embolus originated at 9 o'clock looping downwards and coiled to 12 o'clock. Retrolateral of tibia with long white hairs. Tegulum slightly bulbous and cup-like anteriorly and posterior lobe partially extended to tibia.

Material Examined. Philippines, Luzon island, Batangas Province, Lipa City, Marauoy, Villa de Lipa I, $13^{\circ} 57^{\prime} 47.1^{\prime \prime N}$ $121^{\circ} 09^{\prime} 40.9^{\prime \prime E}$, holotype male (VDL 10) taken from young cacao leaves, 16 January 2019, ATBarrion.

Etymology. Named after the type locality.

\section{Literature Cited}

Barrion, A. T., A. A. Barrion \& A. L. A. Barrion. 2000. Checklist of Philippines Spiders. Laguna: Museum of Natural History, UP Los Baños, College. 17pp.

Barrion, A.T \& J.A. Litsinger. 1995. Riceland Spiders of South and Southeast Asia. International Rice Research Institute, Philippines \& CAB International, Wallingford, United Kingdom. 736pp.

Frendenschuss M. \& M. Seiter. 2016. Four new species of jumping spiders from the Philippines, with description of the male Phintella piatensis Barrion and Litsinger, 1995 (Araneae: Salticidae). Arhtropoda Selecta, 25(1):85-97.

Koh, J.K.H. \& L. T. Ming. 2014. Spiders of Borneo with Special Reference to Brunei. Opus Publications, Kota Kinabalu, Malaysia. 357pp.

Prószyński, J. 2009. Redescriptions of 16 species of Oriental 
Salticidae (Araneae) described by F. Karsch, E. Keyserling and C.L. Koch, with remarks on some related species. Arthropoda Selecta, 18: 153-168.

Simon, E. 1899. Contribution à la faune de Sumatra. Arachnides recueillis par M. J. L. Weyers, à Sumatra. (Deuxiéme mémoire). Annales de la Société Entomologique de Belgique, 43: 78-125.

Żabka, M. 1988. Salticidae (Araneae) of Oriental, Australian and Pacific regions, III. Annales Zoologici, Warszawa 41: 421-479. 